\title{
An Analysis of Renewable Energy Consumption Efficiency in Terms of Greenhouse Gas Production in Selected European Countries
}

\author{
Ladislav Rozenský, ${ }^{*}$ Miroslav Hájek, Zdeněk Vrba,* Richard Pokorný, \\ Justin Michael Hansen, and Jan Lípa
}

\begin{abstract}
The consumption of renewable energy sources results in the minimal production of greenhouse gases. However, the issue of environmentally efficient use of renewable energy sources remains a key concern. The primary aim of this article was to assess whether the energy production from renewable energy sources was environmentally efficient in four selected European countries: Germany, Austria, Poland, and the Czech Republic. In order to achieve the primary research goal, a regression analysis method was used for several variables. The results of the analysis suggested that with an increase in the consumption rate of renewable energy sources and biofuels equivalent to one thousand tons of oil, the volume of emissions from all sectors would increase by 0.0048 thousand tons (4.8 tons) on average. The system of emission allowances was rather environmentally inefficient at the lower allowance levels; in the monitored period of 2007 to 2016, the dependence of greenhouse gas production on the consumption of fossil fuels did not statistically manifest itself. Based on the analysis, the land use, land-use change, and forestry production activities do not contribute to increasing total greenhouse gas emissions.
\end{abstract}

Keywords: Environmental policy; Renewable energy consumption; Woodchips; Land use, land-use change, and forestry (LULUCF); EU ETS

Contact information: Department of Humanities in Medicine, $1^{\text {st }}$ Faculty of Medicine, Charles University, Karlovo náměstí 40, Praha 212800 Czech Republic; *Corresponding author: Rladislav@seznam.cz

\section{INTRODUCTION}

The consumption of wood chips can be counted as an important contribution to renewable energy resources (Jiang et al. 2017). According to the latest Eurostat statistics (European Statistical System), this segment (wood chip consumption) is growing faster than any other renewable energy type (Eurostat 2019). Presently, when there is a surplus of pulpwood on the market, usage as a fuel is one of the possible uses of this energy source (Hájek et al. 2019). This can help reduce the economic losses of forest owners, e.g., after the calamity from the overpopulation of Ips typographus in Europe (Vakula et al. 2015). It should be noted that the combustion of wood chips is not an entirely pure renewable energy. During its combustion, the sequestered carbon is released back into the atmosphere. However, there is a so-called substitution effect in which the combustion of wood chips can replace the combustion of solid fuels that have a higher proportion of carbon and other pollutants (Hájek et al. 2019).

The main objective of this work was to assess whether the consumption of renewable energy sources is environmentally efficient. The secondary goal was to evaluate other factors and how they affect greenhouse gas emissions in the monitored countries. 
To better understand the context above, the following research questions have been raised: (1) whether the consumption of renewable energy sources (RES) contributes to the reduction of $\mathrm{CO}_{2}$ emissions; (2) whether the European Union Emission Trade Market (EU ETS) contributes to reducing $\mathrm{CO}_{2}$ emissions in the selected countries; (3) whether land use, land-use change, and forestry (LULUCF) production activities contributes to increasing greenhouse gas emissions; and (4) whether the consumption of solid fuels contributes to an increase in $\mathrm{CO}_{2}$ emissions.

Environmental policy uses several tools in order to meet the needs of environmental protection. Institutional instruments are utilized along with other instruments; the individual components of which are chosen by states according to the priorities of their environmental policy (Hájek et al. 2019). Emission tradable allowances, which are also dealt with in the analysis put forth in this paper, can be classified together with carbon taxes and excise duties among indirect, economic instruments (Yegorova 2013). However, the European Union's LULUCF program and the promotion of the consumption of renewable energy sources, as well as their substitution for the consumption of fossil fuels, falls within the framework of institutional instruments for environmental protection (Hájek et al. 2019).

\section{Renewable Energy Consumption}

Outside of wood chip combustion, the consumption of renewable energy sources does not cause the release of greenhouse gases. The substitution of such gases for solid fossil fuels ultimately leads to a reduction in total greenhouse gas production (Rozenský et al. 2019). The consumption of renewable resources is supported by the policies defined by the country, which is based on the support from the state for their usage (Kharlamova et al. 2018). The overall consumption of renewable energy sources is growing, according to Eurostat (Statistical Agency of the European Union) statistics (Eurostat 2019). The largest increase in time horizons was achieved by the combustion of wood chips (Khattak et al. 2020). It should be noted that wood chips release greenhouse gases during combustion, especially $\mathrm{CO}_{2}$, and thus releases the carbon sequestered by the growth of wood into the air (Zeng et al. 2019). Nonetheless, its substitution for other fossil fuels with a higher carbon content ultimately reduces the production of greenhouse gases (Hájek et al. 2019). Additionally, the processing of degraded pulpwood and wood waste into wood chips appears to be one of the possibilities for processing the wood waste and residues generated as a byproduct during forestry and wood production (Ul Hai et al. 2019).

\section{Land Use, Land-use Change, and Forestry}

On 30 May 2018, the European Parliament and the EU Council adopted a regulation regarding the inclusion of greenhouse gas emissions and their absorption due to land use, land use change, and forestry in the 2030 climate and energy policy framework and amended Regulation (EU) No. 525/2013 and Decision No. 529/2013/EU. Thus, EP (European Parliament) and Council Regulation EP 2018/841, titled LULUCF measures, was implemented. In doing so, the European Parliament and EU Council considered the fact that the land use, land use change, and forestry (LULUCF) sectors could potentially deliver long-term climate benefits and therefore make a major contribution to achieving the Union's greenhouse gas reduction target in addition to the long-term goals of the Paris Agreement (Pistorius et al. 2017). The principle of the LULUCF program is primarily based on reporting the amount of sequestered nitrogen (Ellison et al. 2014). However, this is only in the broader sense. In a narrower sense, this reporting must be understood as a whole set of measures and activities, often of a production nature, which leads to an 
increased degree of carbon sequestration and its preservation in biomass, e.g., wood. In the field of forestry, these are primarily educational interventions in young stands and afforestation and crop protection (Gonzales-Garcia et al. 2014). During these activities, greenhouse gases are also released through production or transport. Analyzing the relationship between carbon sequestration activities and its correlation with greenhouse gas emissions can lead to the knowledge necessary to reduce these emissions.

\section{EU ETS (European Emission Trade System)}

The EU ETS is a common instrument of the European Union designed to reduce greenhouse gases (Hájek et al. 2019). Some authors classify this instrument as an indirect economic instrument for air protection. In this model, it is represented as a variable in terms of greenhouse gas production. Due to the research goals of this work, the theory of this tool will not be given more space.

\section{EXPERIMENTAL}

\section{Materials}

The objective of this study was to assess the research on environmental effectiveness. For this purpose, the data were created in order to form a timeline, from which the charts were then compiled for a more comprehensive understanding of the problem. Next, a regression analysis was performed, which attempted to assess the remaining objectives. Another aim was to assess additional factors, as well as to identify how greenhouse gas emissions are affected in the countries under review. The data of four EU Member States (Germany, Austria, Poland, and the Czech Republic) were further analyzed in detail. These are developed EU countries that form a comprehensive territorial European region. All countries selected for this analysis have the same institutional environmental instruments and do not use the voluntary economic instrument, i.e., a carbon tax, outlined by the EU (Lin and Li 2011). The German-speaking countries (Germany and Austria) are developed countries with GDPs (gross domestic product) above $100 \%$ of the EU average. Poland and the Czech Republic are among the newest members of the EU and exhibit dynamic development and GDP growth. All these countries have tradable EU ETS emission allowances in their environmental policy tool mix, a common EU instrument for reducing emissions. These countries also use renewable energy sources, depending on the traditions, environmental policies, geographical location, and geothermal conditions of the country (Chen et al. 2020). All the above-mentioned EU member states also use LULUCF measures as another instrument part of the common EU environmental policies.

\section{Methods}

The effects of renewable energy sources on the amount of $\mathrm{CO}_{2}$ production were analyzed in detail. Since the used model affected other factors and tools, e.g., the EU ETS or the consumption of fossil fuels, the authors used a regression analysis, which concluded that it was a suitable research method to assess the synergistic effect of several factors on the research goals. Greenhouse gas emissions (expressed in tons per year of $\mathrm{CO}_{2}$ per capita) are the basic dependent variable. These data were pulled from the European Statistical Office, section "Statistic A-Z." (Eurostat 2019). The emission allowance prices are an explanatory variable. The emission allowance price was chosen as a variable because the EU ETS is a fundamentally obligatory regulatory element. The data were obtained from 
the European Energy Exchange and from the Energy Regulatory Office (ERU 2020). A unit is the average annual emission allowance in the EUR per 1 allowance. The consumption of fossil fuel is an explanatory variable, which was chosen because the consumption of fossil fuels relates to greenhouse gas emissions. The consumption of renewable energy is an explanatory control variable in our model. Their substitution for energy from the combustion of fossil fuels containing carbon has the ultimate effect of reducing the total greenhouse gas production. The data were obtained from the Eurostat database for which the per capita amount and year for the population of the country was calculated as of the $31^{\text {st }}$ of December of the respective year according to the Eurostat database in our calculation model (Eurostat 2019). These data were reported by converting the consumption of renewable energies into their tons of oil equivalent. In the case of this variable, the theoretical expectations were negative, i.e., with the increasing consumption of renewable energies, there is a decline in greenhouse gas production. The LULUCF program must be understood as a set of activities and production processes leading to the provision of measures resulting from this European Regulation, as well as production activities leading to its goal, i.e., the promotion of carbon sequestration and its balance. The Eurostat database "Land use, land use change and forestry" served as a source for this timeline (Eurostat 2019). This variable was identified as the primary goal of the research, assuming the volume of bound carbon, or related activities, does not have a major effect on the increase of greenhouse gases. For the analysis of the data from 2007 to 2016 (carbon sequestration within LULUCF, greenhouse gas emissions, emission allowance price, consumption of solid fuels, and the consumption of renewable energy sources), regression and correlation analyses were used.

Regression analysis allows one to get information about the dependence of quantitative characteristics (Litschmannová 2011). The $Y$ variable, whose behavior is explained in this research, is called a dependent variable (the explained variable). The $X$ variable, whose behavior explains the behavior of the dependent $Y$ variable, is called an independent variable (Hindls et al. 2002). Correlation analysis deals with interdependdencies, emphasizing the strength or intensity of the relationship (Bílková et al. 2009). In most cases, the linear regression equation used can be defined as Eq. 1,

$$
\eta=\beta_{0}+\beta_{1} x
$$

where $\eta$ is unknown, $\beta_{0}$ is a parameter (the intercept), and $\beta_{1}$ is another parameter (the slope).

The intensity of the dependence was measured using a determination index (Budíková et al. 2010). If the dependency function is validated, the determination index is 1 (and vice versa if the value is 0 ). The Pearson correlation coefficient, for the two variables $X$ and $Y$, was also calculated (Croissant and Millo 2008). Additional indicators were also analyzed via elementary statistical analysis with the selected characteristics as follows: position, variability, and concentration (median, variance, standard deviation, kurtosis, and skewness). The following hypotheses were verified in this paper: (1) $\mathrm{H}_{0}$ : there was no linear relationship between the $X$ (LULUCF) and $Y$ (GHG emission levels) variables; (2) $H_{0}$ : there was no linear relationship between the $X$ (emission allowance price) and $Y$ (level of greenhouse gas emissions) variables; (3) $H_{0}$ : there was no linear relationship between the $X$ (consumption of fossil fuels) and $Y(\mathrm{GHG}$ - green house gas emission level) variables; and (4) $H_{0}$ : there was no linear relationship between the $X$ (consumption of RES) and $Y$ (level of greenhouse gas emissions) variables. 
For testing the hypotheses, the fixed probability error of the first type (so-called materiality level) was chosen to be $5 \%$ (Shmueli 2010). Significance tests of the regression parameters were performed in order to determine if the correlation between the sample variables was strong enough to be considered as proven for the base set.

\section{RESULTS AND DISCUSSION}

\section{Graphic Analysis}

The following graphs show the course of the explained emission variable and the individual explanatory variables.

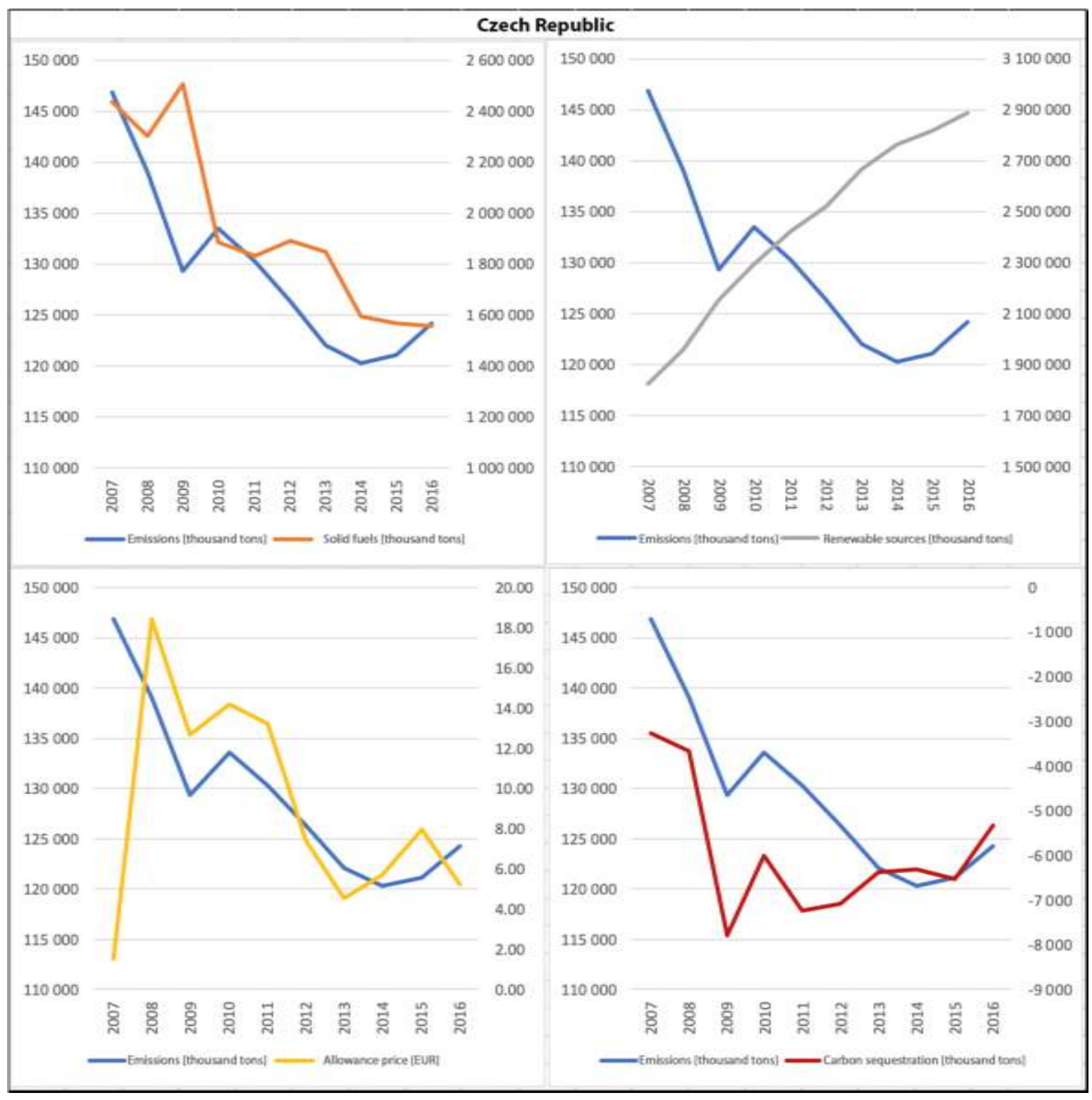

Fig. 1. Relation of the explanatory variables to the explanatory (Czech Republic) 


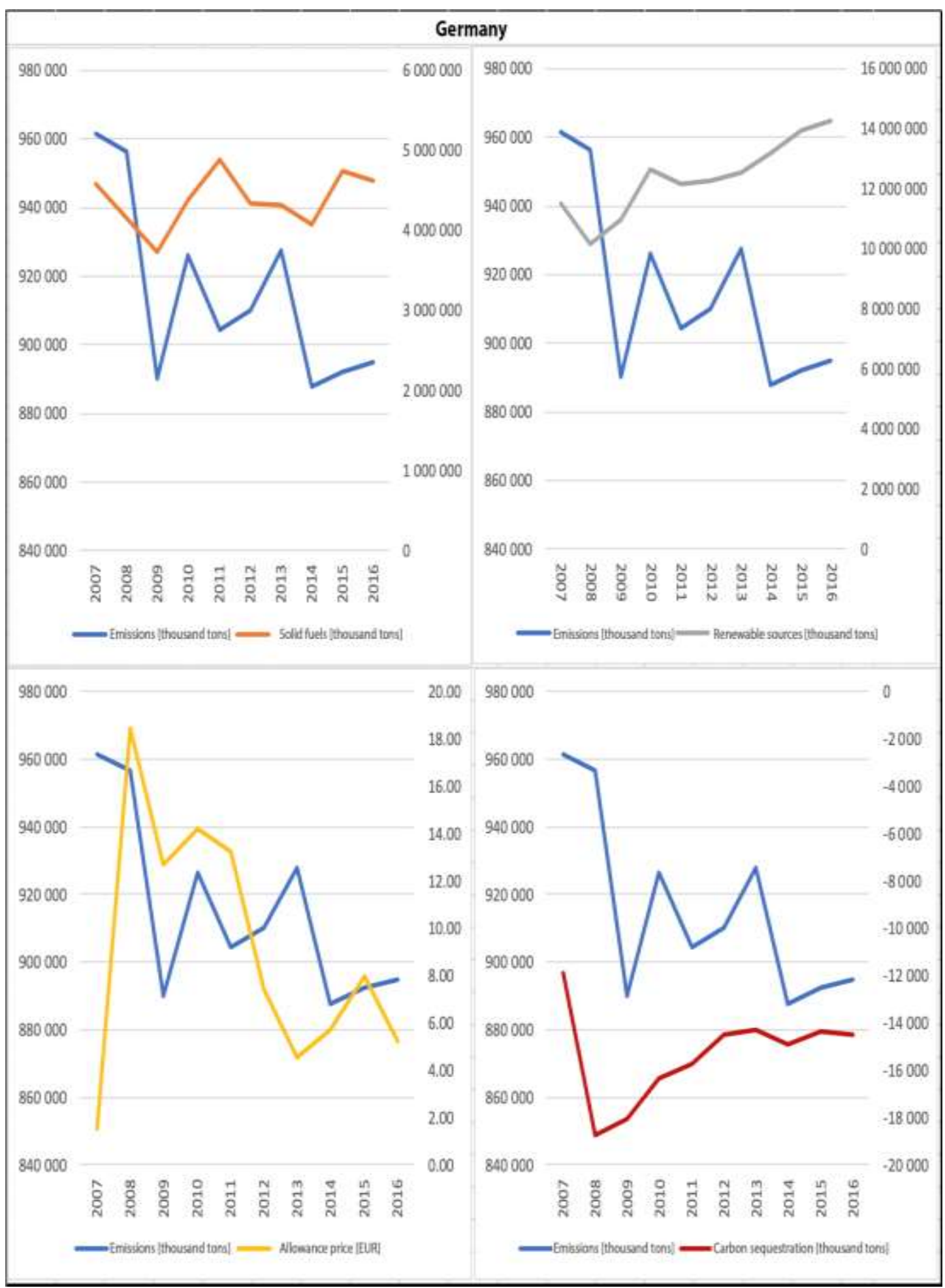

Fig. 2. Relation of the explanatory variables to the explanatory (Germany) 


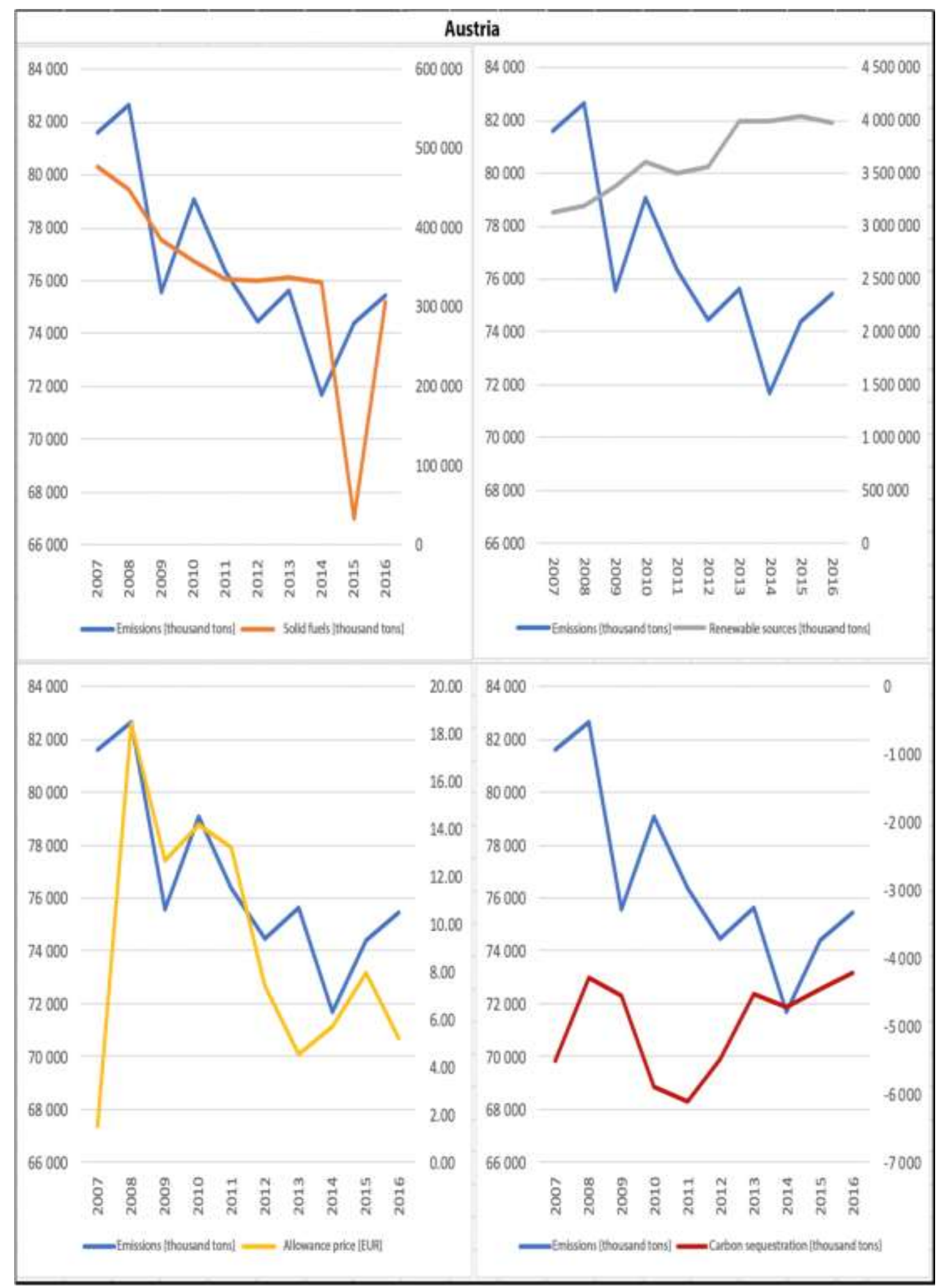

Fig. 3. Relation of the explanatory variables to the explanatory (Austria) 


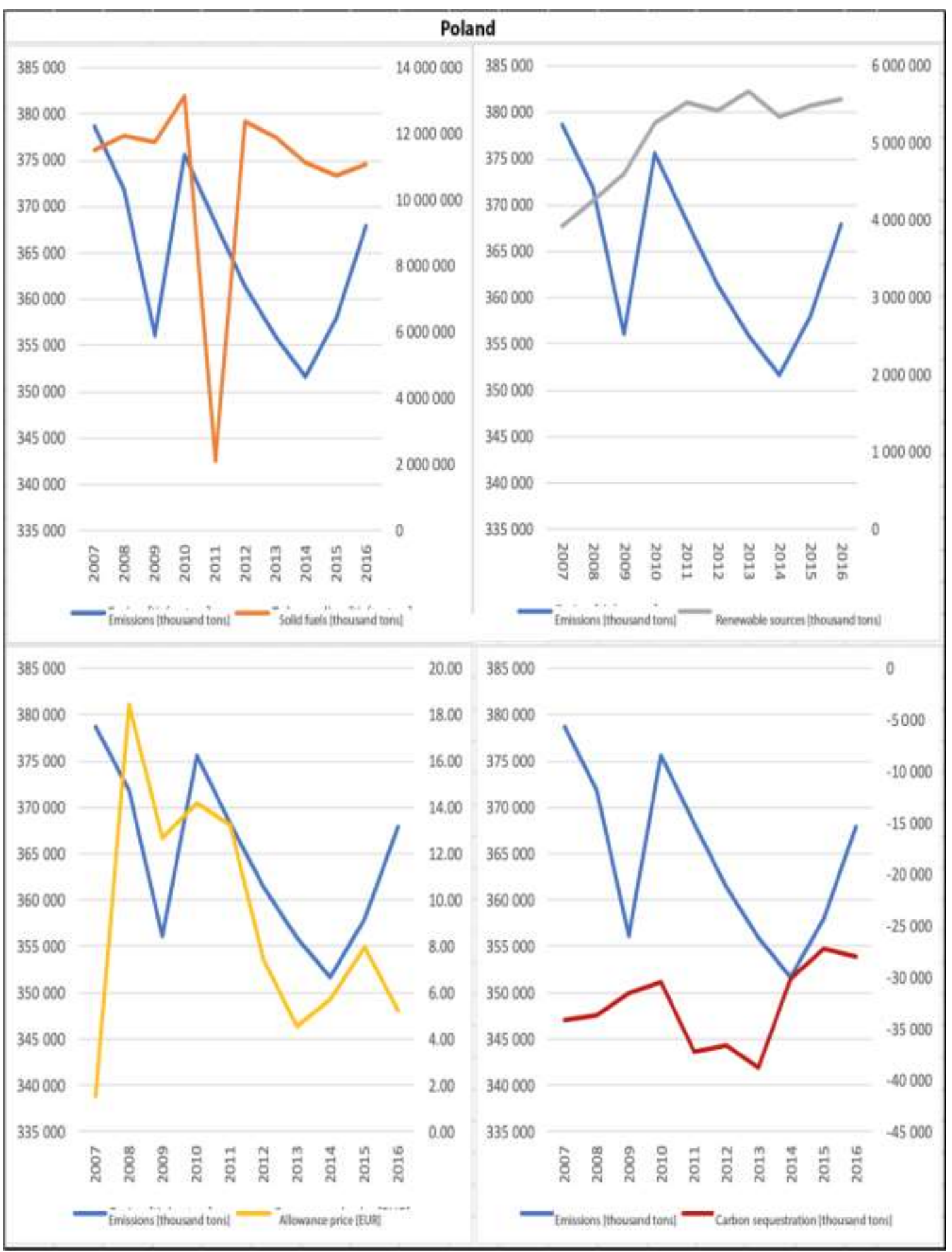

Fig. 4. Relation of the explanatory variables to the explanatory (Poland)

The values of the Pearson's correlation coefficient are shown in Table 1. The value always expresses the correlation of the explained variable "emissions" (volume of emissions from all sectors in the territory of the given country) with the individual explanatory variables listed in the columns for individual countries listed in the rows. 
Table 1. Pearson Correlation Coefficient

\begin{tabular}{|c|c|c|c|c|}
\hline \multicolumn{2}{|c|}{} & \multicolumn{3}{c|}{ Pearson Correlation Coefficient } \\
\hline & $\begin{array}{c}\text { Solid } \\
\text { Fuel }\end{array}$ & $\begin{array}{c}\text { Renewable } \\
\text { Sources }\end{array}$ & $\begin{array}{c}\text { Allowances } \\
\text { Prize }\end{array}$ & $\begin{array}{c}\text { Carbon } \\
\text { Sequestration }\end{array}$ \\
\hline $\begin{array}{c}\text { Czech } \\
\text { Republic }\end{array}$ & $76.4 \%$ & $-92.9 \%$ & $19.7 \%$ & $69.4 \%$ \\
\hline Germany & $6.7 \%$ & $-60.0 \%$ & $8.1 \%$ & $7.5 \%$ \\
\hline Austria & $58.0 \%$ & $-77.2 \%$ & $35.7 \%$ & $-15.7 \%$ \\
\hline Poland & $-4.7 \%$ & $-49.2 \%$ & $19.3 \%$ & $-5.5 \%$ \\
\hline
\end{tabular}

Table 2. Pearson Correlation Test

\begin{tabular}{|c|c|c|c|c|}
\hline \multicolumn{4}{|c|}{ Pearson Correlation Test } \\
\hline & Solid Fuel & Renewable Sources & Allowances Prize & $\begin{array}{c}\text { Carbon } \\
\text { Sequestration }\end{array}$ \\
\hline $\begin{array}{c}\text { Czech } \\
\text { Republic }\end{array}$ & $\mathbf{0 . 0 1}$ & $\mathbf{0 . 0 0}$ & 0.59 & $\mathbf{0 . 0 3}$ \\
\hline Germany & 0.85 & 0.07 & 0.82 & 0.84 \\
\hline Austria & 0.08 & $\mathbf{0 . 0 1}$ & 0.31 & 0.52 \\
\hline Poland & 0.60 & 0.20 & 0.73 & 0.60 \\
\hline
\end{tabular}

The values can be interpreted as follows: $100 \%$, there is a $100 \%$ correlation between the emission variable and the given explanatory variable, i.e., as the explanatory variable increases, so do the emissions; $0 \%$, there is a $0 \%$ correlation between the emission variable and the given explanatory variable, i.e., the variables are independent of each other; and $-100 \%$, there is a $-100 \%$ correlation between the emission variable and the given explanatory variable, i.e., as the explanatory variable increases, the emissions decrease.

Table 2 shows the p-values for the Pearson correlation test. If a significance level of $5 \%$ was chosen and the value in Table 2 was less than 0.05 , then a statistically significant correlation between the emission variable and the explanatory variable in the column for the country in the row could be made.

\section{Panel regression}

Due to the situation in which four units (four states) were found, along with four explanatory variables, one cannot use the random effects method. Therefore, 3 models of fixed effects were used. For the panel data models, the fixed effects represented the constants for individual units.

\section{Model with fixed effects estimated using LSDV (least squares dummy variable) method}

If the least squares dummy variable (LSDV) method is used, a dummy variable is assigned to each unit, as shown in Eq. 2,

$$
y_{\mathrm{it}}=\beta_{0}+\beta_{1} x_{\mathrm{it}}+\alpha_{\mathrm{i}} D_{\mathrm{i}}+e_{\mathrm{it}}
$$

where $y_{\mathrm{it}}$ is the dependent variable (DV) emission volume ( $i$ - country; $t$ - time), $\beta_{0}$ is the control parameter for zero ground ( 0 ), $x_{\mathrm{it}}$ is the independent variable (IV) allowance price, $\beta_{1}$ is the coefficient for IV, $D_{\mathrm{i}}$ is the dummy variable for units (states), $\alpha_{\mathrm{i}}$ is the coefficient for units (states), and $e_{\text {it }}$ is the random component. 
Table 3. Model with the Fixed Effects Estimated Using the LSDV Method

\begin{tabular}{|c|c|c|c|c|c|}
\hline Fixed Effect & Estimate & Std. Error & $t$ Value & $\operatorname{Pr}(>|\mathrm{t}|)$ & \\
\hline Solid Fuels & $-9.000 \mathrm{e}-04$ & $1.0812 \mathrm{e}-03$ & -0.8786 & 0.386149 & \\
\hline Renewable Sources & $-1.3429 \mathrm{e}-02$ & $4.5584 \mathrm{e}-03$ & -2.9460 & 0.005959 & ${ }^{* *}$ \\
\hline Allowance Prices & $-2.2098 \mathrm{e}+02$ & $3.9808 \mathrm{e}+02$ & -0.5551 & 0.582675 & \\
\hline Carbon Sequestration & $1.2654 \mathrm{e}+00$ & $9.4965 \mathrm{e}-01$ & 1.3325 & 0.192112 & \\
\hline Factor Czech & $1.7339 \mathrm{e}+05$ & $1.6315 \mathrm{e}+04$ & 10.6274 & $5.010 \mathrm{e}-12$ & $* * *$ \\
\hline Factor Germany & $1.1070 \mathrm{e}+06$ & $6.8109 \mathrm{e}+04$ & 16.2541 & $\begin{array}{c}\text { Less than } \\
2.2 \mathrm{e}-16\end{array}$ & $* * *$ \\
\hline Factor Poland & $4.8686 \mathrm{e}+05$ & $4.8163 \mathrm{e}+04$ & 10.1087 & $1.739 \mathrm{e}-11$ & $* \star * *$ \\
\hline Factor Austria & $1.3416 \mathrm{e}+05$ & $1.9889 \mathrm{e}+04$ & 6.7458 & $1.277 \mathrm{e}-07$ & $* *$ \\
\hline
\end{tabular}

Significance Codes: $0={ }^{* \star *} ; 0.001={ }^{* *} ; 0.01={ }^{*} ; 0.05=. ;$ and $0.1^{\prime}={ }^{\prime} 1$

Based on the p-values of the individual factors (countries), it could be determined that there was a statistically significant dependence on the emission levels in individual countries (at a 5\% level of significance).

The only statistically significant explanatory variable was the total consumption of renewable energy sources and biofuels (at a 5\% level of significance). The other variables were not statistically significant.

The coefficient can be interpreted as follows: with an increase of the total consumption of renewable energy sources and biofuels by a one thousand tons of oil equivalent, the volume of emissions from all sectors decreased by 0.0134 thousand tons (13.4 tons) on average. The interpretation always depends on the estimated intersection or factors of the given countries.

Fixed effects estimated using the "within estimator"

In the case of using the "within estimator", each observation is adjusted using time centering, as shown in Eq. 3,

$$
y_{i t}-\bar{y}_{\iota}=\beta_{1}\left(x_{i t}-\overline{x_{\imath}}\right)-a_{i}-\overline{a_{\iota}}+e_{i t}-\overline{e_{l}}
$$

where $y_{\mathrm{it}}$ is the dependent variable (DV) emission volume ( $i$, country; $t$, time), $\bar{y}_{l}$ is the average DV over time for each group, $x_{\mathrm{it}}$ is the independent variable (IV) allowance price, $\bar{x}_{l}$ is the mean IV over time for each group, $\beta_{1}$ is the coefficient for time-centered IV, $\alpha_{\mathrm{i}}$ is the unknown intersection for each unit (state), $\overline{a_{l}}$ is the average intersection for each unit (state), $e_{\text {it }}$ is the random component, and $\overline{e_{l}}$ is the average of the random component over time for each group.

Because $a_{\mathrm{i}}$ is a constant equal to its diameter, the relationship shown in Eq. 4 is true.

$$
a_{i}-\overline{a_{\imath}}=0
$$

The original equation can thus be rewritten in the following form, as shown in Eq. 5 ,

$$
\ddot{y_{i t}}=\beta_{1} \ddot{x_{l t}}+\ddot{e_{i t}}
$$

where $\ddot{y_{l t}}$ is the time-centered dependent variable (DV) emission volume ( $i$, country; $t$, time), $\overline{x_{l t}}$ is the time-centered independent variable (IV) allowance price, $\beta_{1}$ is the coefficient for time-centered IV, and $\overline{e_{l t}}$ is the time-centered random component. 
Table 4. Model with the Fixed Effects Estimated Using the "Within Estimator"

\begin{tabular}{|c|c|c|c|c|c|}
\hline $\begin{array}{c}\text { Test of } \\
\text { Coefficients }\end{array}$ & Estimate & Std. Error & $t$ Value & $\operatorname{Pr}(>|t|)$ & \\
\hline Solid Fuels & $-9.5000 \mathrm{e}-04$ & $3.5207 \mathrm{e}-03$ & -0.2698 & 0.7890 & \\
\hline $\begin{array}{c}\text { Renewable } \\
\text { Sources }\end{array}$ & $-1.3429 \mathrm{e}-02$ & $2.8450 \mathrm{e}-03$ & -4.7202 & $4.473 \mathrm{e}-05$ & $* * *$ \\
\hline Allowance Prices & $-2.2098 \mathrm{e}+02$ & $2.3179 \mathrm{e}+02$ & -0.9534 & 0.3476 & \\
\hline $\begin{array}{c}\text { Carbon } \\
\text { Sequestration }\end{array}$ & $1.2654 \mathrm{e}+00$ & $1.4596 \mathrm{e}+00$ & 0.8669 & 0.3924 & \\
\hline
\end{tabular}

Significance Codes: $0={ }^{* \star *} ; 0.001={ }^{* \star} ; 0.01{ }^{*} ; 0.05=. ;$ and $0.1^{\prime}={ }^{\prime} 1$

The estimates of the parameters using the "within estimator" were the same as the estimations calculated using the LSDV method. However, the p-values describing the significance of the individual variables were different. Even so, only one explanatory variable remained, the consumption of renewable energy sources and biofuels. Nevertheless, a statistical increase in the solid fuel variable could also be interpreted.

\section{Model with the fixed effects estimated using the first differences method}

Because $a_{i}$ is a constant, using the first differences method resulted in Eq. 6,

$$
\Delta y_{i t}=\beta_{2}\left(x_{i t}-x_{i t-1}\right)+e_{i t}-e_{i t-1}
$$

where $\Delta y_{i t}$ is the change of dependent variable (DV) emission volume over time ( $i$ country; $t$ - time), $x_{\mathrm{it}}$ is the independent variable (IV) allowance price at time $t, x_{\mathrm{it}-1}$ is the independent variable (IV) allowance price at time $t-1, \beta_{2}$ is the coefficient for the first difference IV, $e_{\text {it }}$ is the random component at time $t$, and $e_{\mathrm{it}-1}$ is the random component at time $t-1$.

Table 5. Model with the Fixed Effects Estimated Using the First Differences Method

\begin{tabular}{|c|c|c|c|c|c|}
\hline $\begin{array}{c}\text { Test of } \\
\text { Coefficients }\end{array}$ & Estimate & Std. Error & t Value & $\operatorname{Pr}(>|\mathrm{t}|)$ & \\
\hline Intercept & $-3.9507 \mathrm{e}+03$ & $1.6294 \mathrm{e}+03$ & -2.4246 & 0.021346 & $*$ \\
\hline Solid Fuels & $3.3177 \mathrm{e}-04$ & $2.4293 \mathrm{e}-04$ & 1.3657 & 0.181870 & \\
\hline $\begin{array}{c}\text { Renewable } \\
\text { Sources }\end{array}$ & $4.7563 \mathrm{e}-03$ & $1.3946 \mathrm{e}-03$ & 3.4106 & 0.001819 & $* *$ \\
\hline Allowance Prices & $3.5327 \mathrm{e}+02$ & $2.7230 \mathrm{e}+02$ & 1.2974 & 0.204083 & \\
\hline $\begin{array}{c}\text { Carbon } \\
\text { Sequestration }\end{array}$ & $4.8516 \mathrm{e}-01$ & $3.1504 \mathrm{e}-01$ & 1.5400 & 0.133708 & \\
\hline
\end{tabular}

Significance Codes: $0={ }^{* *} ; 0.001={ }^{* *} ; 0.01={ }^{*} ; 0.05=. ;$ and $0.1^{\prime}={ }^{\prime} 1$

The only statistically significant explanatory variable was the consumption of renewable energy sources and biofuels. The other variables were not statistically significant. The coefficient can be interpreted as follows: with an increase of the total consumption of renewable energy sources and biofuels by a one thousand tons of oil equivalent, the volume of emissions from all sectors increased by 0.0048 thousand tons (4.8 tons). The interpretation always depends on the estimated intersection. In this case, the model showed negative emissions with the assumption that all four explanatory variables were equal to 0 (which is not possible). Therefore, the model estimated by the LSDV model in combination with correlation analysis seemed to be the best fit. 
It could be said that the renewable energy variable had a negative effect on the emission variable (correlation coefficient). This was in addition to the fact that the relationship of the renewable energy variable to the emission variable was statistically significant, in terms of the analyzed panel data from the four selected countries during the period of 2007 to 2016.

Based on the performed analysis and the created model, it can be generally stated that the dependent variable (greenhouse gas emissions per capita) and its development had greater effects over a longer period of time.

This is partially due to the influence of the behavior of the economic entities, i.e., the consumption of solid fuels (households and companies) and the consumption of renewable energy sources (households and companies). However, the impact of the economic instruments introduced to protect the environment and climate are also responsible; these are represented in the model presented in this article, both directly through tradable emission allowances (price of tradable emission allowances) and indirectly through the amount of subsidy support for renewable energy sources (which affects consumption of renewable energy sources and their substitutes).

Before proceeding to the interpretation of the results, it should be noted that independent variables do not act on the dependent variable alone, but rather the two act at the same time, i.e., both changes in the behavior of economic agents and economic instruments affect $\mathrm{CO}_{2}$ emissions over the same time period.

The consumption of solid fuels (hard coal, brown coal, and coke) theoretically increases the amount of greenhouse gas emissions in the economy. From the point of view of further reducing greenhouse gas emissions, it is therefore appropriate to reduce the consumption of solid fuels. There is room for individual economic entities (households and companies) to introduce more environmentally friendly methods of heating, new and economical technologies, or energy savings. From the point of view of the government, or the view of a regulator in general, there is room for the use of economic instruments for the internalization of negative externalities.

The consumption of renewable energy sources (electricity and heat from the sun, wind, water, biomass, biogas, etc.) has a negative effect, in part, on the total greenhouse gas emissions within the selected panel, but the individual results differ by country. However, it can be stated that the consumption of renewable energy sources contributed to a reduction in total $\mathrm{CO}_{2}$ emissions. This again created space for a number of regulatory government measures to support the use of renewable energy sources by economic entities (households and companies), in the case of both electricity and heat generation.

The variable amounts of sequestered carbon within the LULUCF sections did not show a statistically significant effect on the greenhouse gas emissions variable. It could therefore be interpreted that activities leading to the promotion and sequestration of carbon do not have a significant effect on the increase of greenhouse gases.

Based on the obtained results, it can be summarized that the chosen method of panel regression was suitable for evaluating the environmental efficiency of the substitution consumption of renewable energy sources. These results also confirmed the insignificant impact of LULUCF-related activities in terms of the level of greenhouse gases. The model also showed that in selected countries, these instruments were more effective than the emissions trading system, which is currently the primary instrument used in common environmental policy within the field of air protection.

As previously mentioned, the instruments of environmental protection are chosen by individual governments, which when combined operate in synergy, depending on the 
chosen environmental policies of individual states (Hájek et al. 2019). Most of the institutional instruments are commonly implemented in EU member states due to them being common EU environmental policy. Some instruments are optional, such as the carbon tax, which is enforced within the EU, especially by the Nordic countries (Rozenský et al. 2019). In addition to the instruments mentioned above and analyzed, the most important common instruments within the EU's common policy are as follows: excise duties, limits, investments by companies and households in environmentally friendly technologies, and a system of subsidies and advances (Lin and Li 2011).

The performed analysis was consistent with the results of analyses published by Hájek et al. (2019) and Rozenský et al. (2019). Here, the synergy effects of carbon emission allowances, solid fuel consumption, renewable energy sources, company investments in environmental technologies, taxes, and carbon taxes in member countries that have this voluntary instrument in place were analyzed and were examined relations emissions on GDP. The results of these analyses indicated that a carbon tax seemed to be the most effective tool, especially for countries that had it in place for a longer time period (Hájek et al. 2019). Emission allowances appeared to be ineffective; however, they depended on their lowest market price. Surprisingly, the dependence of $\mathrm{CO}_{2}$ emissions on the total GDP did not manifest itself here, probably due to the economic crisis of 2004 to 2008 and the orientation of developed countries towards trade and services along with the transfer of industrial production abroad. The fact that there were delayed effects on individual measures also played a role (Alden 2008). The effect of the consumption of renewable energy sources seemed to be the most effective tool here, by a significant amount. Furthermore, the results obtained could be compared with the analysis of Lin and Le (2011), who performed the same analysis with similar results and published list of three results - the effects of a carbon tax, lower efficiency of emission allowances and significant efficiency of renewable energy consumption. All 3 surveys interpreted the low dependence of greenhouse gas production on the GDP of a county. Similar results were achieved in selected categories in this research. This published analysis did not show a statistically significant correlation between the consumption of solid fuels for greenhouse gas production. Among other things, this may be due to the ongoing economic crisis during this period and the delayed effects of the observed variable over time.

The author's analysis built on the analyses described above and focused on quantifying the environmental efficiency of renewable energy consumption in addition to dealing with the relationship between the dependence of LULUCF production activities on greenhouse gas production.

\section{CONCLUSIONS}

1. The renewable variable had a negative effect on the emission variable (correlation coefficient). The consumption of renewable resources (and their substitution for fossil fuels) was indeed environmentally efficient and with the consumption of renewable energy sources, the production of greenhouse gases may decrease. With an increase of the total consumption of renewable energy sources and biofuels by a one thousand tons of oil equivalent, the volume of emissions from all sectors increased by 0.0048 thousand tons (4.8 tons).

2. The consumption of solid fuels had no statistically significant positive partial effect on

Rozenský et al. (2020). "Review of greenhouse gas," BioResources 15(4), 7714-7729.

7726 
the production of greenhouse gases.

3. The emissions trading system was a less effective tool with low emission allowance prices.

4. Any land-use change, and forestry (LULUCF)-related activities did not have an impact on greenhouse gas growth. The interpretation was always dependent on the estimated intersection. In this case, the model showed negative emissions, assuming that all four explanatory variables are equal to 0 (which is not possible).

5. The causal interpretations that could be deduced from the results were derived from the fact that the relationship between the renewable energy variable and emission variable was statistically significant, in terms of the panel data analyzed from the four selected countries from 2007 to 2016.

\section{ACKNOWLEDGEMENTS}

1. This paper was supported by the "Advanced Research Supporting the Forestry and Wood-processing Sector's Adaptation to Global Change and the $4^{\text {th }}$ Industrial Revolution" (Grant No. CZ.02.1.01/0.0/0.0/16_019/0000803), and financed by project No. QK1920391, which was financed by the Ministry of Agriculture of the Czech Republic called "Diversification of the Impact of the Bioeconomy on Strategic Documents of the Forestry-Wood Sector as a Basis for State Administration and the Design of Strategic Goals by 2030 ".

2. This paper was additionally supported by the institutional support of Charles University, First Faculty of Medicine, Institute of Humanities in Medicine, Katerinská 32, CZ - 121, Prague 2, Czech Republic, EU.

\section{NOTE}

This article was translated by a native speaker, an academic from the University of Oregon, who is also a co-author of the work.

\section{REFERENCES CITED}

Alden, C. (2008). "Screen on the green," Green Futures 67, pp. 32-34.

Bílková, D., Budinský, P., and Vohánka, V. (2009). Pravděpodobnost a Statistika [Probability and Statistics], Vydavatelství a nakladatelství Aleš Čeněk, Plzeň, Czech Republic.

Budíková, M., Králová, M., and Maroš, B. (2010). Průvodce Základními Statistickými Metodami [Guide to Basic Statistical Methods], Grada, Prague, Czechia.

Chen, T., Wang, Y., Wang, J., Li, L., and Cheng, P. (2020). "Multistage decision framework for the selection of renewable energy sources based on prospect theory and PROMETHEE," International Journal of Fuzzy Systems 22, 1-17. DOI: 10.1007/s40815-020-00858-1.

Croissant, Y., and Millo, G. (2008). "Panel data econometrics in R: The plm package," 
Journal of Statistical Software 27(2), 1-43. DOI: 10.18637/jss.v027.i02

Ellison, D., Lundblad, M., and Petersson, H. (2014). "Reforming the EU approach to LULUCF and the climate policy framework," Environmental Science and Policy 40, 1-15. DOI: 10.1016/j.envsci.2014.03.004

ERU (2020). (https://www.eru.cz/en/poskytovani-informaci), Accessed January 1, 2020.

European Commission (EC) Regulation 2018/842 (2018). “ Regulation (EU) 2018/842 of the European Parliament and of the Council of 30 May 2018 on binding annual greenhouse gas emission reductions by Member States from 2021 to 2030 contributing to climate action to meet commitments under the Paris Agreement and amending Regulation (EU) No 525/2013," European Union, Brussels, Belgium.

Eurostat (2019). "Statistic A - Z," (https://ec.europa.eu/eurostat/data/statistics-a-z/abc), Accessed January 1, 2020.

González-García, S., Dias, A. C., Clermidy, S., Benoist, A., Maurel, B. V., Gasol, C. M., Gabarrell, X., and Arroja, L. (2014). "Comparative environmental and energy profiles of potential bioenergy production chains in Southern Europe," Journal of Cleaner Production 76, 42-54. DOI: 10.1016/j.jclepro.2014.04.022

Hájek, M., Zimmermannová, J., Helman, K., and Rozenský, L. (2019). “Analysis of carbon tax efficiency in energy industries of selected EU countries," Energy Policy 134, 1256-1268. DOI: 10.1016/j.enpol.2019.110955

Hindls, R., Seger, J., and Hronová, S. (2002). Statistika pro Ekonomy [Statistics for Economists], Professional Publishing, Průhonice, Czechia.

Jiang, W., Searle, S., and Siddiqui, S. (2017). "Analysis of the global wood-chip trade's response to renewable energy policies using a spatial price equilibrium model," Biofuels, Bioproducts 11(3), 505-510. DOI: 10.1002/bbb.1761.

Kharlamova, G., Stavytskyy, A., and Nate S. (2018). "Estimation of renewable energy sources application in the synergy with European union policy," Bulletin of Taras Shevchenko National University of Kyiv. Economics 3(198), 54-65. DOI: 10.17721/1728-2667.2018/198-3/7

Khattak, S. I., Ahmad, M., Khan, Z. U., and Khan, A. (2020). "Exploring the impact of innovation, renewable energy consumption, and income on $\mathrm{CO}_{2}$ emissions: New evidence from the BRICS economies," Environmental Science and Pollution Research 27(12), 13866-13881. DOI: 10.1007/s11356-020-07876-4

Lin, B., and Li, X. (2011). "The effect of carbon tax on per capita $\mathrm{CO}_{2}$ emissions," Energy Policy 3(9), 5137-5146. DOI: 10.1016/j.enpol.2011.05.050

Litschmannová, M. (2011). Vybrané Kapitoly z Pravděpodobnosti [Selected Chapters of Probability], VŠB-TU Ostrava, Ostrava, Czechia.

Pistorius, T., Reinecke, S., and Carrapatoso, A. (2017). "A historical institutionalist view on merging LULUCF and REDD+ in a post-2020 climate agreement," International Environmental Agreements: Politics, Law and Economics 17(5), 623-638. DOI: 10.1007/s10784-016-9330-0.

Rozenský, L., Vrabcová, P., Hájek, M., Veselá, T., and Hukal, P. (2019). "Searching for correlations between $\mathrm{CO}_{2}$ emissions and selected economic parameters," Statistika: Statistics and Economy Journal 99(2), 151-162.

Shmueli, G. (2010). “To explain or to predict?," Statistical Science 25(3), 289-310. DOI: 10.1214/10-STS330

Ul Hai, I., Sher, F., Yaqoob, A., and Liu, H. (2019). “Assessment of biomass energy potential for SRC willow woodchips in a pilot scale bubbling fluidized bed gasifier," Fuel 258, 258-270. DOI: 10.1016/j.fuel.2019.116143 
Vakula, J., Zúbrik, M., Galko, J., Gubka, A., Kunca, A., Nikolov, C., and Bošel'a, M. (2015). "Influence of selected factors on bark beetle outbreak dynamics in the Western Carpathians," Central European Forestry Journal 61(3), 149-156. DOI: 10.1515/forj-2015-0023

Yegorova, Y. N. (2013). "Economic tools of environmental protection," Izvestia Uralskogo Gosudarstvennogo Ekonomiceskogo Universiteta 50(6), 140-146.

Zeng, T., Kuptz, D., Schreiber, K., Schön, C., Schulmeyer, F., Zelinski, V., Pollex, A., Borchert, H., Loewen, A., Hartmann, H., et al. (2019). "Impact of adhering soil and other extraneous impurities on the combustion and emission behavior of forest residue wood chips in an automatically stoked small-scale boiler," Biomass Conversion and Biorefinery 9(1), 99-116. DOI: 10.1007/s13399-018-00368-z

Article submitted: June 22, 2020; Peer review completed: August 15, 2020; Revised version received and accepted: August 19, 2020; Published: August 25, 2020.

DOI: 10.15376/biores.15.4.7714-7729 